ERIA Discussion Paper Series

\title{
Towards a Truly Seamless Single Windows and Trade Facilitation Regime in ASEAN Beyond 2015
}

\author{
Jonathan $\mathrm{KOH}^{*}$ \\ CrimsonLogic Pte Ltd \\ Andrea Feldman MOWERMAN ${ }^{\dagger}$ \\ CrimsonLogic Pte Ltd
}

November 2013

\begin{abstract}
:
The current status of trade facilitation measures including the ASEAN Single Window initiative is reviewed and assessed. Similar initiatives for trade facilitation in other parts of the world are also appraised, and recommendations for further enhancements for ASEAN trade facilitation are proposed.
\end{abstract}

Keywords: ASEAN, Trade Facilitation; Single Window; Regional Integration

JEL Classification: F13, F15, F55, F40, N45

\footnotetext{
* Jonathan Koh is Director, Trade Facilitation Centre of Excellence, CrimsonLogic Pte Ltd

${ }^{\dagger}$ Andrea Mowerman is a graduate student at the Lee Kwan Yew School of Public Policy National University of Singapore, and was an intern at CrimsonLogic from May to Jul 2013
} 


\section{Introduction}

Trade facilitation is an ever-evolving term that has changed its elements and connotations as the world has become more integrated and production more fragmented. In a "narrow sense, trade facilitation efforts could simply address the logistics of moving goods through ports or more efficiently moving documentation associated with cross-border trade" (Wilson, et al., 2009). A broader definition establishes that trade facilitation is "the simplification and rationalization of customs and other administrative procedures that delay or increase the cost of moving goods across international borders” (ADB, 2009). More recently this definition has broadened even further to include terms such as celerity, transparency, traceability, standards, technology, red tape and harmonization among others.

Trade facilitation has increased its importance worldwide since the mid 1900's and in the Asian region became a trend after the 1997-1998 crises when many countries realized that it was not enough to be export oriented economies. To fully integrate to a globalized world, countries had to become trade oriented. To be able to accomplish this task, governments must allocate part of their budget and staff to be able to accomplish the "reduction of tariff rates of protection, and application of information and telecommunication technology to speed transactions” (Wilson, et al., 2009). As seen above, trade facilitation is not limited to the reduction or elimination of tariffs. Today, it encompasses a significant change of policies and implementation of new processes to reduce bureaucratic red tape and redundant border controls as well as investments in technology and training for government staff.

Investing in trade facilitation creates benefits for the government as well as the private sector. Concisely, "the benefits of trade facilitation are not exclusive to the business community. Trade facilitation reforms can generate significant welfare gains for the economy as a whole. The APEC Economic Committee has estimated that trade facilitation measures committed to date will add $0.25 \%$ of real GDP to APEC (about USD\$46 billion in 1997 prices) by 2010, compared to economic gains from trade liberalization measures (tariff removal) amounting to $0.16 \%$ of real GDP (about USD\$30 billion)”(Wao and Wilson, 2000). 
Improving trade logistics has a significant effect on trade competitiveness resulting in increased private investment in key tradable sectors, encouraging exports and thus creating employment ${ }^{1}$.

Reducing trade transaction costs is a necessary complement to economic liberalization for developing countries to effectively participate in regional and global markets. The movement of cargo is not limited only by their geographical locations, but by border restrictions. This is especially true for agricultural trade, which has the least amount of added value; hence any increase in price can potentially decrease access of these goods in foreign markets.

\section{Trade Facilitation in ASEAN}

The Association of Southeast Asian Nations (ASEAN) member countries, have made a series of commitments in order to be able to facilitate trade amongst themselves and more recently their main trade partners. These efforts become the pillar of a functional economic and trading system given the increase in trade fragmentation, manufacturing specialization and the fact that no longer goods hold a single origin for their denomination.

In an initial stage in 1992, the initial 5 ASEAN member states (Brunei, Indonesia, Thailand, Philippines, Malaysia and Singapore) agreed to establish the ASEAN Free Trade Area. The commitment amongst these countries is focused in lowering intra-regional tariffs by means of the implementation of the Common Effective Preferential Tariff (CEPT) which established that all goods produced and traded amongst the member countries would have a 0-5\% tariff by the year 2015 . Further to this initial commitment the additional ASEAN countries (Myanmar, Vietnam, Cambodia, and Lao PDR) joined the AFTA, agreeing to the same conditions, but in a longer term, by the year 2015.

In addition to the tariff related commitments, the working group also included a series of trade facilitation initiatives to be included amongst the activities to be pursued under the AFTA. Given the moment in which these discussions took place (early 1990's), automation was out of the scope. Rather the efforts were basically 
focused on the harmonization of Customs procedures, lowering tariffs, implementing WTO valuation standards and tariff harmonization. Implementing these changes would set a common ground for trade to take place in the region, all traders and government having a clear understanding of how to interact with government officials as well as amongst themselves.

Clearly, with the passing of time and the reality of the world, these efforts are not sufficient. Decreasing tariffs and duties relieves some of the burdens existing for intra ASEAN trade, but the core inconveniences are related to activities that need to take place in order for cargo to be mobilized amongst countries. The World Bank Doing Business benchmark study analyzes the cost and time needed for a "standard" cargo 20-foot container to enter and leave a country. As it will be noted below, nontariff barriers, such as licensing, excessive cargo manipulation, red tape, and bureaucratic procedures can increase the cost of trading goods up to an additional $60 \%$ of the cost of cargo at origin. This is not a real issue when the goods traded are of high added value, i.e. electronics, technology goods, fine leather goods, but when the cargo traded is of low added value (agricultural goods, basic textiles and apparel) a steep increase in price caused by external factor can mean a decrease in competitiveness for the goods produced in these countries, or even worst, the complete shutdown of trade in those areas. Below is a comparative table amongst the ASEAN member states and the burdens in time and cost "soft" issues have on the effectiveness of their trade transactions. 
Table 1: Doing Business 2013 Trading Across Borders Indicators

\begin{tabular}{|c|c|c|c|c|c|c|c|}
\hline \multicolumn{8}{|c|}{ Time for Document Processing and Cargo Handling } \\
\hline Country & $\begin{array}{l}\text { Worldwide } \\
\text { ranking }\end{array}$ & $\begin{array}{c}\text { Document } \\
\text { preparation } \\
\text { and cargo } \\
\text { handling } \\
\text { (days- } \\
\text { export) } \\
\end{array}$ & $\begin{array}{c}\text { Total } \\
\text { days } \\
\text { DB }\end{array}$ & $\begin{array}{l}\text { Percentage } \\
\text { of time } \\
\text { spent in } \\
\text { processing } \\
\text { (exports) }\end{array}$ & $\begin{array}{c}\text { Document } \\
\text { preparation } \\
\text { and cargo } \\
\text { handling } \\
\text { (days- } \\
\text { export) } \\
\end{array}$ & $\begin{array}{l}\text { Total } \\
\text { days } \\
\text { DB }\end{array}$ & $\begin{array}{l}\text { Percentage } \\
\text { of time } \\
\text { spent in } \\
\text { processing } \\
\text { (imports) }\end{array}$ \\
\hline Brunei & 40 & 16 & 19 & $84.21 \%$ & 14 & 15 & $93.33 \%$ \\
\hline Cambodia & 118 & 20 & 22 & $90.91 \%$ & 23 & 26 & $88.46 \%$ \\
\hline Malaysia & 11 & 8 & 11 & $72.73 \%$ & 6 & 8 & $75.00 \%$ \\
\hline Myanmar & NA & NA & NA & NA & NA & NA & NA \\
\hline Lao PDR & 160 & 22 & 26 & $84.62 \%$ & 22 & 26 & $84.62 \%$ \\
\hline Philippines & 53 & 13 & 15 & $86.67 \%$ & 13 & 14 & $92.86 \%$ \\
\hline Singapore & 1 & 3 & 5 & $60.00 \%$ & 3 & 4 & $75.00 \%$ \\
\hline Indonesia & 37 & 14 & 17 & $82.35 \%$ & 21 & 23 & $91.30 \%$ \\
\hline Thailand & 20 & 12 & 14 & $85.71 \%$ & 12 & 13 & $92.31 \%$ \\
\hline Vietnam & 74 & 19 & 21 & $90.48 \%$ & 20 & 21 & $95.24 \%$ \\
\hline \multicolumn{8}{|c|}{ Time for Document Processing and Cargo Handling } \\
\hline Country & $\begin{array}{c}\text { Worldwide } \\
\text { ranking }\end{array}$ & $\begin{array}{c}\text { Cost of } \\
\text { cargo } \\
\text { handling } \\
\text { (export) }\end{array}$ & $\begin{array}{c}\text { Total } \\
\text { costs } \\
\text { DB }\end{array}$ & $\begin{array}{l}\text { Percentage } \\
\text { of cost } \\
\text { spent in } \\
\text { processing } \\
\text { (exports) }\end{array}$ & $\begin{array}{c}\text { Cost of } \\
\text { cargo } \\
\text { handling } \\
\text { fees } \\
\text { (Import) }\end{array}$ & $\begin{array}{c}\text { Total } \\
\text { costs } \\
\text { DB }\end{array}$ & $\begin{array}{l}\text { Percentage } \\
\text { of cost } \\
\text { spent in } \\
\text { processing } \\
\text { (imports) }\end{array}$ \\
\hline Brunei & 40 & $\$ 480$ & $\$ 680$ & $70.85 \%$ & $\$ 545$ & $\$ 745$ & $73.15 \%$ \\
\hline Cambodia & 118 & $\$ 585$ & $\$ 755$ & $77.48 \%$ & $\$ 700$ & $\$ 900$ & $77.78 \%$ \\
\hline Malaysia & 11 & $\$ 265$ & $\$ 435$ & $60.92 \%$ & $\$ 255$ & $\$ 420$ & $60.71 \%$ \\
\hline Myanmar & NA & NA & NA & NA & NA & NA & NA \\
\hline Lao PDR & 160 & $\$ 540$ & $\$ 2.146$ & $25.16 \%$ & $\$ 525$ & $\$ 2.125$ & $24.71 \%$ \\
\hline Philippines & 53 & $\$ 415$ & $\$ 585$ & $70.94 \%$ & $\$ 475$ & $\$ 660$ & 71.97\% \\
\hline Singapore & 1 & $\$ 315$ & $\$ 456$ & $69.30 \%$ & $\$ 299$ & $\$ 439$ & $68.11 \%$ \\
\hline Indonesia & 37 & $\$ 484$ & $\$ 644$ & $75.16 \%$ & $\$ 500$ & $\$ 660$ & $75.76 \%$ \\
\hline Thailand & 20 & $\$ 385$ & $\$ 585$ & $65.81 \%$ & $\$ 540$ & $\$ 750$ & $72.00 \%$ \\
\hline Vietnam & 74 & $\$ 410$ & $\$ 610$ & $67.21 \%$ & $\$ 400$ & $\$ 600$ & $66.67 \%$ \\
\hline
\end{tabular}

As the charts above detail, in many cases the bulk sum and the majority of days are invested in obtaining documentation and actually getting the cargo to mobilize. Further proof of the above can be noted in the World Bank Trade Logistics Viewpoint where it is noted that "high transactions costs related to trade are driven by how public policies, regulations, and procedures interact with import and export supply chains. Indeed, "software" issues—such as processing trade-related documents and fulfilling clearance requirements by customs and other technical control agencies - account for more than 50-60 percent of the total time to export and import in many countries around the world"2. Given the above situation, ASEAN 
countries have moved forward and began the implementation of the ASEAN Economic Community (AEC).

\subsection{From ASEAN to AEC: Trade Specific Commitments}

Further to the AFTA, in more recent times ASEAN member states foreseeing the need to develop further intraregional trade agreed to sign and actively participate in the accomplishment of the goals drafted within the ASEAN Economic Community (AEC) blueprint ${ }^{3}$. This blue print traces the path to full-on ASEAN economic integration and is focused not only on trade related facilitation, but rather includes areas of potential regional convergence such as movement of skilled labor, trade in services, foreign direct investment etc.

In regards to trade facilitation specific commitments, it was stipulated that all ASEAN member states will abide and implement the improvements included in the text by the year 2015. For some countries this has meant sharing their knowhow and international best practices related to trade procedures (i.e. Singapore, Malaysia etc). In other cases this has meant massive amounts of investment and training, to be able to shift trade customary procedures up to par (i.e. Indonesia, Malaysia, Thailand, Philippines).

As it was noted in the introduction of the paper, solving the "soft" trade issues can generate great benefits to traders and exporting countries. As noted by the World Bank's Trade Logistics Reforms Viewpoint, “trade logistics reforms have a notable effect on the ability of countries to export and import cost-effectively and to become effective players in competitive global and regional markets. Second, trade facilitation enhances the productivity of firms. And third, targeted reforms can enable firms to use scarce working capital more effectively by allowing leaner inventories, lowering the carrying charges in transit and storage, and reducing pilferage and damage ${ }^{4 »}$. The efforts countries make to facilitate trade not only impact traders in a positive manner, rather the entire economy as a whole is benefitted from these efforts.

The AEC was conceived in 2007 as one of the three pillars to achieve ASEAN regional unity. It is divided into four main pillars. These are: 
- Single market and production base

- Competitiveness

- Economic Development

- Integration of the region to the global economy ${ }^{5}$

To be able to accomplish the above mentioned goals, a series of initiatives have to take place, which require vast government commitment and private sector cooperation. In this sense, ASEAN governments have been issuing a series of legislative pieces in order to be able to implement the improvements they have agreed to comply with by the year 2015. Some of these commitments include an agreement on the trade of goods (further to what was agreed upon with the AFTA), an agreement on the trade of services, an investment agreement, freight service agreement, intellectual property rights agreement, consumer protection agreement, taxation agreement and e-commerce agreement. The goal of these agreements is to "provide a streamlines, consolidated, predictable and transparent set of rules to achieve the goals". 6

In regards to trade-specific commitments, in accordance to the AEC blueprint, what is sought for are "simple, harmonized and standardized trade and customs, processes, procedures and related information flows (which) are expected to reduce transaction costs in ASEAN (and) which will enhance export competitiveness and facilitate the integration of ASEAN into a single market for goods, services and investments and a single production base”. ${ }^{7}$

In more specific terms, trade facilitation reforms include:

- Integration of customs structures

- Modernization of tariff classification, customs valuation practices and origin determination

- Establish an ASEAN e-Customs

- Improve customs clearance processes

- Strengthen human skillsets

- Adopt risk management and audit based controls

There are a series of additional commitments, but the ones explained above are directly related to the successful implementation of an ASEAN Single Window as a platform for electronic trade in the ASEAN region, offering traders and regional governments security and celerity for their trade transactions at a regional level. 
Furthermore, the ASEAN Single Window will allow for greater B2G interaction to be done at a whole-of-government level, and not just at “individual agency” level, thus allowing for trade transaction to take place in a more transparent and cohesive manner.

\subsection{ASEAN Single Window}

In December 2005, the ten ASEAN member States signed an "Agreement to Establish and Implement the ASEAN Single Window” (“ASW Agreement”). This was followed by a "Protocol to Establish and Implement the ASEAN Single Window” (“ASW Protocol”) in December 2006.

The objectives of this Protocol are:

a. To provide a legal and technical framework to establish and implement the ASEAN Single Window (ASW) and National Single Windows (NSWs) as regional commitments towards the establishment of an ASEAN Economic Community;

b. To strengthen the coordination and partnership among Lead agencies/ASEAN Customs Administrations and relevant line ministries and agencies and economic operators (importers, exporters, transport operators, express industries, customs brokers, forwarders, commercial banking entities and financial institutions, insurers, and those relevant to the international supply chain) to effectively and efficiently implement the ASW;

c. To encourage participation of economic operators to the implementation of the ASW and NSWs; and

d. To provide technical, functional and operational guidance for the implementation of the ASW and NSWs in Member Countries as set forth in the ASW Agreement, taking into consideration the ASW Technical Guide.

These treaties envisage that the ASEAN member States will first operationalize their National Single Windows ("NSWs") by specified deadlines, before proceeding to accomplish the more complex task of establishing the ASEAN Single Window (for which no deadline was provided in the treaties).

The ASEAN Single Window ("ASW") is defined in the agreement as "The environment where National Single Windows of Member Countries operate and integrate”, where "The National Single Window is a system which enables:

- a single submission of data and information; 
- a single and synchronous processing of data and information; and

- a single decision-making for customs release and clearance. A single decision-making shall be uniformly interpreted as a single point of decision for the release of cargoes by the Customs on the basis of decisions, if required, taken by line ministries and agencies communicated in a timely manner to the Customs"

In March 2006, the ASEAN Secretariat published the ASW Technical Guide, which clearly states the vision and perspectives of the ASEAN Single Window:

"The ASEAN Single Window (ASW) is a trade-facilitating environment operating on the basis of standardized information parameters, procedures, formalities, international best practices as relevant to the release and clearance of cargoes at entry points of ASEAN under any particular customs regime (imports, exports, and others). It pursues a more accelerated release of cargoes being shipped to, and from ASEAN in order to reduce transaction costs and time required for customs clearance in the region. The ASW should also be seen as part of the global supply chain and of the logistics industry working for the effective realization of the ASEAN Economic Community.”

The original timeline for the implementation of first six AMS namely Brunei Darussalam, Indonesia, Malaysia, Philippines, Singapore and Thailand to complete its respective National Single Windows (NSW) by 2008, while remaining four AMS, the CLMV countries (Cambodia, Lao PDR, Myanmar and Vietnam) to complete their NSW by 2012. Subsequently these timeline have been pushed to 2012 and 2015 respectively.

Customs modernization involves the simplification of procedures, which includes the removal of "red tape" at the border. National Single Windows take this one step further, by allowing traders to complete all of their regulatory requirements through a nationwide border control system. The next logical step is to facilitate the exchange of cross-border information between both governments and the private sector, which would be achieved by implementing the ASEAN Single Window.

A National Single Window plays a vital role in meeting the trade facilitation objectives of governments which, in simple terms, are to reduce clearance times at the border. Nevertheless, while the objectives of implementing a National Single Window are the same for each of the Member States, their regulatory requirements 
are very different. The objective of the ASEAN Single Window, therefore, is not to impose any regulatory requirements at the regional level. It simply provides an environment for National Single Windows to operate and integrate.

In the ASEAN Single Window, ASEAN member states have agreed to implement an advanced form of Single Window integration i.e. the one that generates full seamless connectivity between national Single Windows. It is to be noted that when implemented properly, this can facilitate trade, lesser bureaucratic burdens for traders, optimize government staff and budget and increase competitiveness. According to the AEC blueprint, "the implementation of measures of simplifying, harmonizing and standardizing trade and customs, processes, procedures and the application of ICT in all areas related to trade facilitation would be paramount in the ultimate creation of an ASEAN Single Window". 8

The benefits of implementing the ASEAN Single Window are therefore likely to become more and more evident over the next few years, as each of the Member States embark on trade facilitation improvements programmes and implement their National Single Windows. When all ten National Single Windows have been integrated through the ASEAN Single Window, it would not be unreasonable to expect ASEAN to be the easiest region in the world to trade with.

\subsubsection{ASEAN Single Window Timelines}

The ASEAN Single Window has been conceived as an effort all ASEAN member states have to make in order for the region to interact as a single unit regarding any foreign trade transactions. The ASEAN Single Window will allow the ASEAN member states to standardize trade related processes (licensing, documentation, inspections processes etc.) in such a way that third party traders and governments communicate with all countries in block. Amongst themselves the countries benefit the members by not only lowering tariffs, but by acknowledging standardization efforts, and sharing sensitive information about traders and goods. Additionally, allowing for a "single block" trade amongst Southeast Asian nations will allow for a stronger negotiation platform, given its closest commercial competing neighbors - China and India. 
ASEAN member states have agreed that their NSW will be fully operational by the year $2015^{9}$ prior to beginning the implementation of the ASW. Ideally, the role of the ASW is to integrate the NSW of all ASEAN member states and create a single platform in which traders and government agencies submit trade (cargo) related information in a single space and all approvals, processing and payments necessary are done in a seamless manner. Additionally, the ASW will include a trade repository, capacity building programs for the public and private sector, and implementation of existing best practices in the region.

ASEAN region governments have been in the process of updating their legislation and staff in order to be able to embrace the change that will begin to take place in full force as of the year 2015. Some countries such as Singapore and Malaysia who have been modernizing their trade systems and processes since the late 90's and early 2000's have less modifications to make, as they have functioning systems. Rather, their role is to share best practices and lessons learnt in such a way that work are not duplicated in the other countries in the region.

\section{2015 Assumptions and ASEAN Members NSW Reality}

Based on the Protocol detailed above, by the year 2015 all 10 ASEAN member states must have fully functional NSW that can be interconnected amongst themselves to form the ASW. To be noted, this not only means that the NSW connect, this means that all local technical control agencies acting in trade transactions, be it at the front end in cargo manipulation processes or the back end issuing licenses, controlling the usage of import and/or export quotas, and the payment of royalties. All these agencies have to be connected in a seamless manner to the NSW. With all agencies integrated in the NSW platform, cargo handling, documentation issuance and cargo release will be done in a more effective manner.

Clearly, this is a task that is easier said than done, mostly given the existing disparities among the ASEAN countries in regards to automation of government systems. Below is an image of the current standing of the ASEAN countries 
regarding the design and implementation of their NSW, as well as its integration to local Customs system.

Table 2:_Status of National Single Window Systems in ASEAN Member States (as of May 2013)

\begin{tabular}{|c|c|c|c|c|}
\hline & $\begin{array}{l}\text { Current } \\
\text { NSW Status }\end{array}$ & $\begin{array}{c}\text { NSW linked } \\
\text { to } \\
\text { Customs } \\
\text { System }\end{array}$ & $\begin{array}{c}\text { NSW } \\
\text { interface } \\
\text { with } \\
\text { Customs }\end{array}$ & $\begin{array}{c}\text { ASEAN Pilot } \\
\text { - ATIGA } \\
\text { Form D }\end{array}$ \\
\hline $\begin{array}{l}\text { Brunei } \\
\text { Darussalam }\end{array}$ & $\begin{array}{c}\text { Implementi } \\
\text { ng }\end{array}$ & Pending & Future & Yes \\
\hline Indonesia & Live & Yes & Yes & Yes \\
\hline Malaysia & Live & Yes & Yes & Yes \\
\hline Philippines & Partial & Pending & Future & Yes \\
\hline Singapore & Live & Yes & Yes & Yes \\
\hline Thailand & Live & Yes & Yes & Yes \\
\hline Cambodia & No status & NONSW & Possibly & No \\
\hline Myanmar & No status & No NSW & Unknown & No \\
\hline Lao PDR & No status & NONSW & Unknown & No \\
\hline Vietnam & No status & No NSW & Yes & Yes \\
\hline
\end{tabular}

\section{USAID Program}

Given the disparities detailed above, USAID has decided to support the implementation of the ASW. The program is composed of three components that are detailed as follows:

- Component 1: establishing the ideal network architecture to conduct the ASW pilot without using a central server. In this sense, it is handy to clarify that ASEAN countries have not yet established if ASW will be a central platform which processes all requests incoming to the region and connects to the agencies within the countries that have to interact in a specific part of the trade process, or rather, there are not a central platform and simply interconnect the NSW under a single user interphase, but keeping all systems independent.

- Component 2: setting up the agreed infrastructure to implement the ASW Pilot Project. This component, given its complexity has been divided into 2 subcomponents - a scaled-down pilot and a later scaled-up pilot to test the recommended architecture under component 1. In 2012 the scaled-down pilot 
was implemented on 7 ASEAN countries ${ }^{10}$. This pilot tested the exchange of ASEAN Customs Declaration Document (ACDD) and ASEAN Trade in Goods Agreement (ATIGA) Form D data among the participating AMS. Messages include test data only. Funding for the scaled-up pilot is yet to be secured.

- Component 3: Evaluation and viability analysis of the pilot project. Given that Component 2 is still pending the scaling-up phase of the initiative, this element has not been done.

Parallel to these specific IT related components, member countries are currently in the process of analysing the existing legal gaps (mainly countries that are yet to implement their NSW) and issuing the necessary legislation, based on the regional best practices, in order to be able to implement the ASW in a seamless manner. Legislation to be issued can include topics such as e-commerce, e-banking, digital signature, validity or proof or digital support documents, archives of digital documents, etc ${ }^{11}$.

Additionally, government representatives involved in the ASW have done extensive consultations with the private sector in order to begin assessing the capacity building needs traders and their intermediaries may have with the implementation of NSW and further the ASW.

As can be noted above, there are still significant monetary and human efforts that need to take place in order to make the dream of all ASEAN countries having a functional NSW by 2015. Even further manpower and monetary efforts are needed to be able to implement the ASW, and further to this, find the necessary infrastructural and legal support for information to flow in a free, seamless manner at a regional level among B2G and G2G.

\section{Examples of Successful Cases of Regional Integration Initiatives}

It is important to note that there are examples of success in digital integration amongst developing countries in other regions of the world. Latin America, Africa and Asia all have success cases that are showcased worldwide as international best practices and can be replicated in other regions. 


\subsection{Digital Certificates of Origin between Colombia, Chile, Mexico and the Andean Community of Nations}

Under the Ministry of Trade, Industry and Tourism during form Minister Plata's mandate, Colombia was the first country in the Latin America and Caribbean region to design and implement Digital Certificates of Origin. Based on the existing Free Trade Agreements with the main regional counterparts (Andean Community of Nations, CARICOM, G-3, Chile, ALADI) and the ongoing negotiations with the USA and the EU, as well as technical and financial assistance from the IADB the effort invested in implementing this tool was completely logical.

Before the implementation of the tool, traders went to the office of the Ministry of Trade's national or regional offices (today they go to Customs), to submit a set of forms which include the sworn origin form and the percentage of origin form. After this, the Ministry issued the Certificate of Origin in original physical form signed and stamped by the authorized government official. When using this methodology, traders have to submit the request and wait for the staff at the Ministry to sign and stamp their certificates in the order they wish, not in the order in which requests were submitted. Human error is always present in these transactions as is the possibility of losing or misplacing documents. Additionally, traders had to pay an average UDS\$5 dollars per certificate issued. The occurrence of these situations, as well as the pay practically disappears with the implementation of the digital certificate of origin. It is important to keep in mind that unless two or more nations agree to acknowledge this form of support document as original, countries will continue to use the physical certificate as a valid support document to trade amongst them.

On July 2, 2009 by means of Decision Number 4 of the Commission of the Free Trade Agreement among Colombia and Chile the parties involved acknowledged the validity of the digital certificate of origin to be sent amongst both nations. Further to this accomplishment, in September 2009 full digital documentary exchange with Mexico and by May 2012 the country was able to exchange digital forms of this document with ALADI countries. On the other hand, Chile issues $50 \%$ of its origin certificates for Colombia on a digital form and Mexico issues $90 \%$ of them in digital form. Further to the above, in November 2012 the Andean Community of Nations 
issued its decision number 775 by which it acknowledged digital certificates of origin as the support documentation to benefit goods traded amongst the member nations ${ }^{12}$.

According to the OECD "the process to develop the digital Certificate of Origin under the Colombian Single Window for Foreign Trade has as its biggest achievement the expediting of the issuance of the document. Before, the filing and requesting of this document by exporters was done physically, had a series of steps to be followed, which ended up being a process that took 2 or 3 days business days. With the implementation of ICT this process takes an average of 10 minutes to take place, generating significant savings, given that fewer personnel is needed to provide assistance, as well as savings in paper and additional necessary office utilities”13. In brief, the benefits of implementing this tool include:

- 24/7 attention from government official to private sector representatives requesting Certificates of Origin

- Less discretion from government officials as the "first come first serve" principle is applied to all request sent by the platform.

- The authenticity of the signature and document is of $100 \%$ as the signature that supports the document is digital and there is no margin of error

- The arrival of the document to the country of destination is practically granted, unless there is an internet failure. There is no human manipulation of the certificate; hence there is no possibility of losing or damaging the document.

- Availability nation-wide where there is internet

- The transaction is free for exporters or their representatives

In brief, according to Angela Ospina Deputy Director for Foreign Trade at the Colombian Ministry of Trade Industry and Tourism, "the implementation of this tool further facilitates trade transactions and benefits exporting countries greatly. It's an effort well paid off, given the increase in Free Trade Agreements and in volumes of trade. Having this tool allows the government to maximize its staffing resources while at the same benefiting the private sector" ${ }^{\text {14 }}$.

\subsection{Pan Asian E-Commerce Alliance (PAA)}

The Pan Asian E-Commerce Alliance (PAA) was created in 2000 amongst private sector representatives which provide the governments of Singapore, Taiwan 
and Honk Kong electronic customs systems. The idea of this Alliance was to further encourage trade via the usage of electronic documents transferred in a safe and seamless manner amongst importers and exporters. Initially the PAA was composed of 3 members, today it has eleven member countries in Asia ${ }^{15}, 150,000$ organizations ${ }^{16}$ and is expanding to Exchange documents with companies based in the EU, UK and APEC member countries.

The main goal of the PAA is to reduce administrative, stationary, courier and purchasing costs traders have to pay in order to be able to trade. This is done by means of granting proper B2B connection and communication in this platform. This platform allows traders to send cargo related documents across borders. Examples of exchanged documents include commercial invoices, purchase orders, advanced shipment notices, packing lists, bill of lading (BL), air way bill, sea way bill, digital certificates of origin etc. Furthermore the platform allows for traders to have a data repository within it, thus allowing them to have access to older information and not have to fill all applications and information as new on a transaction basis.

To be able to accomplish the above, the PAA has developed the Certification Authority Mutual Recognition Scheme which is basically a robust legal and technical framework that allows member companies to issue and acknowledge digital documents and digital signatures as originals, and gives these the same validity that a physical document during litigation. The PAA has gone as far as to create certification authority, the Pan Asian Certificate Policy Authority whose role is to oversee the usage of these facilitation mechanisms. In addition to the above, the PAA has its own dispute resolution system, in which companies which are unsatisfied with a certain situation can go to an e-commerce expert panel and get their dispute resolved by rulings done by sound technical experts.

But, not only is the private sector benefited by this initiative. Governments where this initiative is active have benefitted from best practices adopted within the international private sector community which have translated into more efficient trade transactions, leaner supply chains and more effective trade community. It is not a coincidence that the countries that have implemented this initiative are also ranked in the highest places in the Doing Business benchmark study. 


\subsection{RADDEx}

African countries have been making a constant effort to ease the burden to trade and constantly improving their customs and ICT. Proof of this is the fact that fortytwo ${ }^{17}$ countries currently use ASYCUDA as a means to automate the interaction between the private sector and customs authorities, and to further enhance customs activities in risk management and cargo selectivity.

Unfortunately there is a downfall to these efforts, even if there are a series of African unions and trade agreements i.e. EAC, COMESA to mention a few, there is little information sharing or cross border interaction amongst the countries in this region. The Revenue Authorities Digital Data Exchange (RADDEx) system is an effort to implement a region-wide system in the future. RADDEx is software that transmits customs declarations data in real time from the trader/customs broker generating the declaration through the borders and transit points until the border of exit or entry of cargo ${ }^{18}$. This allows for the seamless and timely transmission of cargo support data, thus reducing the time to trade, duplication of documents and information and the implementation of cargo risk management (as cargo support information arrives prior to cargo itself to the checkpoints and/or borders). "In East Africa, where RADDEx is fully implemented in Partner Member States, in excess of 900 declarations per day are transmitted from Port of Mombasa in Kenya through Malaba border post at the Kenya/Uganda border. These declarations are accessed by customs officers and clearing agents, days before the goods arrive at the border, often facilitating instant crossing, saving transport costs in excess of $\$ 700$ per day. And these lowered transport costs should directly contribute to a lower end price of the goods when they reach the market place”. 19 The process of implementation of this system has been supported and aided by USAID COMPETE Program and in some occasions by the South African Global Competitiveness Hub (Trade Hub). RADDEx has been implemented in the East African countries as well as in Southern Africa (which has not proven to be successful).

The implementation of RADDEx implied generating consensus with a wide array of players, not only internally in the countries that have implemented it, but also cross border with the government authorities who will be interacting with the 
system and receiving cargo support data through it. Additionally, government official and private sector representative had to undergo extensive training to understand the usage and benefits of the implementation of this system for the countries that use it. This is a very sensitive topic since the implementation of RADDEx implies investments in hardware and software, and many times benefits of the implementation are not obvious in the short term.

Clearly, these efforts have to be met up with mutual recognition agreements, so documents issued by third countries are acknowledged as valid support documents and not an excuse to stop cargo at the border. Furthermore a legal overhaul has to take place in order to be able to establish the legal means to exchange digital information as well as grant validity to digital documents, not only for the purse of data exchange or cargo release, but as legitimate proof in case of any doubt related to a trade transaction.

\section{Recommendations for the Successful Design and Implementation of the ASEAN Single Window}

There is no clear road to follow to successfully implement ASW in a short term. Countries within ASEAN have technological disparities, and varied trading patterns. Singapore, on the one hand has no need to protect nascent or local industries as there is a very limited exporting sector, while countries like Cambodia or the Philippines have strong protectionist policies which can potentially create burdens to trade within the region. The ASW should seek to reduce time, documents and cost to trade, while keeping local and security interests as priorities for all member countries.

ASEAN countries have already made significant efforts to set up a standard and common format for Customs Declarations with the name of "ASEAN Customs Declaration Document (ACDD)”. ACDD was developed using the SAD1 as a basis/reference. Out of the numerous variation of information, piled up by the requirements from each Customs of ASEAN member States, 48 information parameters, commonly required by most of the Member States, have been picked up to compose the ACDD. The current stage of ACDD is that ASEAN member States are still exploring the options on the usage of the ACDD at the regional level. It has 
been decided that as long as the 48 information parameters (except for one Member State who has agreed on 34) are in the national data set of customs, the ASEAN member States is considered to have complied with ACDD.

In addition to the ACDD, ASEAN member states have also agreed in a standard format for Preferential Certificate of Origin called ATIGA Form D, with which various data exchange trials have been conducted among ASEAN countries with satisfactory results. Other Certificates such as Sanitary and Phytosanitary Certificates are also envisaged to be exchanged in digital form through the ASW.

Regardless to the efforts mentioned above, there are huge disparities among ASEAN countries. Singapore, Malaysia, Indonesia, Philippines, and Thailand have already built a functional NSW which means that there is B2G and G2G communication - all agencies involved in trade transaction have been linked to the platform in order to be able to interact through it with the business community. These countries then have different priorities, and should now focus their efforts in designing and testing quality standards and characteristics to be able to expand the usage of the platform to B2B activities, as well as invest their efforts in the reduction of documentation needed to trade. Until today, even best practice countries duplicate information among the cargo support document. Finally, they should aid the more challenged countries and share their installed capacity an best practices in order to expedite the process of setting up their NSW.

Parallel to the above, given that there is no clear definition of the activities that will take place within the ASW platform, ASEAN countries have all embarked in different roads of government agency integration to the system. Brunei and Vietnam have built their Customs Single window, which centers all customs related activity within a same platform through which traders, customs brokers, freight forwarders etc. can file the following support documents: import and export declaration processing, payment and communication with Customs at port level. Thus far, their efforts do not include the integration of other technical control agencies to the platform in the short term.

On the less evolved front, Lao PDR has created trade point portals, to be able to expedite trade transactions at points of entry and exist (land, sea, air) so as to decrease time to trade and congestion in warehousing facilities. Cambodia and 
Myanmar have recently begun building the customs system and digitalizing documents. Thus far, the system does not have B2G or G2G functionalities.

Based on the above considerations, below is a list of short and long term recommendations to be able to accomplish what is stipulated in the Jakarta Protocol regarding the ASW. We propose the implementation of the ASW should take place in a phased approach for two specific reasons. In the first place, phasing the implementation of high-impact trade related improvements generate tangible results in the short term, thus creating momentum as to the success and positive impact that these implementations bring to society. When this momentum and approval is created, proposing or implementing greater in depth reforms is less bureaucratically heavy, as public and private sector have already been sensitize and have an understanding of the efforts made.

\subsection{Short Term Recommendations}

Below are a series of recommendations that, based on the stage of development of al ASEAN countries regarding their National Single Windows could be implemented in the short term to be able to accomplish successful changes in trade transactions. These can be implemented between 2015 and 2020.

Private sector involvement: Given the important role of the private sector in providing input for business process analysis, data standardization and harmonization, consultation with the industry/private sector are crucial. Thus, a regular forum for public-private sector engagement should be held both at the regional and national levels for ASW and NSWs, respectively. This can be via the creation of Steering and Technical committees for the Single Windows.

In addition to the feedback that can be provided by the private sector, the effort to incorporate the private sector is the means to sensitize the private sector in regards to the change in the customs that will take place with the implementation of the ASW. It is not clear what benefits the ASW or NSW will reap for the private sector, rather it is normally perceived as additional investment in technology and connectivity and not in security and effectiveness.

Standardization of procedures: An effective ASW depends on effective and inclusive NSWs. Thus, it is necessary to strengthen and standardize the existing 
NSWs that are at different level of developments, and expedite their development. Finally, National Trade Repositories (NTRs), where traders and government agencies can check tariffs and trade related regulations, as this would generate greater legal security for traders and better understanding with government agencies.

Online payments: The implementation of online payment mechanisms, via the usage of debit cards, credit cards or giro. In addition to the above these payments mechanisms should ideally be extended not only for Customs and the payment of taxes and tariffs. Ideally it will be extended to technical control government agencies that issue licenses, any agency which interacts in trade transactions that has any sort of collection and payment fees for inspections.

Back-office/support documentation digitalization: It is not sufficient to build an online documentary repository or single window. What is really necessary is the digitalization of technical control agency back-offices. The efforts invested in creating facilitation tools may be diminished if government agencies continue to keep documents in physical form in various places in the country. Time to issues licenses will not decrease if all support information is not available in a handy manner. Real efficiencies from ICT come from business process re-engineering and automating the entire re-engineered process.

Digitalization of support documents: As was explained in the Latin American example included within the text above, documents should be digitalized and shared in a digital form, as Certificates of Origin are shared amongst Colombia, Chile and Mexico. The pilot in the ASEAN region can take the international best practice presented in Latin America, or can choose to share other cargo support documents in digital form such as phyto-sanitary certificates, technical standards certificates, etc.

\subsection{Medium and Long Term - Year 2020}

Should ASEAN governments succeed in the implementation of the short term recommendations detailed above, they should move forward in implementing these deeper reforms that will finalize the possibility of accomplishing trade transactions in a seamless manner. These more complex processes can begin to take place in the year 2020, at the latest, when all NSW are up to date, functional and under the same standard. 
Physical infrastructure readiness: All ICT related efforts, be it NSW, ASW or Customs systems will be diminished if road, air and port infrastructure is not readily available for the expedite movement of cargo. Licenses can be issued in one day, but if cargo takes days to move the efforts go unnoticed.

E-commerce legislation: Having E-commence legislation readily issued will allow to reap the full benefits of the ICT efforts invested by the ASEAN countries. This legislation has to include digital signature, digital documentary proof, and clear liabilities regarding the proper way to handle electronic documents. Likewise legislation has to be issued at a local and regional level so information can be shared at a regional level. Disparities can result in trade taking place in a physical manner.

Adoption of integrated risk management border controls to ensure cross border compliance: implementing integrated risk management within the ASW will allow for detailed controls of types of cargo and traders mobilizing cargo in the region. All technical control agencies involved in trade transactions should be able to include their missionary risk criteria within the system in such a way that all possible risks inherent to a shipment can be analyzed to be able to determine its selectivity. Furthermore, ex-post controls should be implemented so as to not leave any trace of doubt of lack of compliance.

Encourage the usage of pre clearance and pre certification programs: The aim of this initiative is to decrease congestion in wet and dry ports and allow for a more expedite physical movement of cargo, thus decreasing costs for the private sector. Additionally, granting local authorities the possibility to have information submitted to them prior to the arrival of cargo generates a better risk assessment and compliance with further security measures.

\section{Conclusions}

Based on the analysis provided and the proven viability of the implementation of these facilitation measures, it can be concluded that, not only is the ASW an effort that will benefit the public and private sector in the short term, but rather it's the first of many automation initiatives to be implemented by ASEAN countries to improve 
their connectivity and interaction with the global business environment. This interaction includes $\mathrm{B} 2 \mathrm{~B}, \mathrm{~B} 2 \mathrm{G}$ and $\mathrm{G} 2 \mathrm{G}$ interaction in such a way to be able to connect the entire trade community.

An additional aspect to be developed in the future for the ASW is the possibility to widen the scope or increase the depth of integration with other countries, not necessarily full-fledged members of ASEAN (India, China, NZ, and Australia). This will allow for not only regional seamless trade, but rather for smoother international trade, where supply chains can be lean and all trade transactions efficient.

Further to the above, to be able to disseminate the benefits of the ASW, it is necessary to set up and establish proper communications mechanisms. These communications mechanisms shall be led by the appropriate government agencies, in charge of advocating trade facilitation.

In conclusion, the ideal scenario for the year 2020 would be full integration of technical control agencies' processes for obtaining all cargo support documents. This would be done via the implementation of digital signatures and online payment systems in such a way that no person to person interaction takes place. Ultimately, via the implementation of the ASW the governments where the cargo is originated will be able to submit documentation electronically to the countries of destination of the cargo in a seamless digital manner prior to the arrival of the cargo, in such a way that risks can be assessed ex-ante and no unnecessary delays would occur in the port or warehouses.

Regarding customs transactions traders should be able to file and submit all import and export declarations (regardless of the modality being used), and this will include the processing of information on the usage of quotas, subsidies or drawbacks. Likewise, via the sage of this system traders should be able to pay all fees and duties related to an export or import transaction via an online payment button. Lastly, given that Customs is the government agency that effectively controls the entrance and exit of cargo to a country it should be the agency in charge of hosting the integrated risk management system, which includes the specific risks of the technical control agencies interacting in trade transactions. These agencies will either introduce themselves or sent to Customs the information regarding the origin of their 
cargo related risk, so it can be inputted into the Customs hosted system and be a part of the security risks analyzed.

On the other hand by 2020 the ASW should include the processing of information regarding port and shipping activities. With this all government agencies involved in trade transactions (not just customs) can be able to verify the risk inherent to specific cargo prior event to the trader filing the import declaration.

As a final consideration, being ahead of the curve of Single Window implementation can potentially harm developed countries, given that these have robust systems based on older legislation and available technology. Sometimes this means loose a competitive edge compared to those countries who took a longer time to implement but end up having a more functional system and up to date system. In this case less developed countries can become a best practice, and countries that used to be trend makers will also have to invest in human capacity building and ICT infrastructure to revamp their systems.

\section{References}

Asian Development Bank (November 2009), 'Designing and Implementing Trade Facilitation in Asia and the Pacific'. Available at: http://aric.adb.org/pdf/Trade_Facilitation_Reference_Book.pdf

Wao Pau, Y. and J. Wilson, (2000), New Directions for APEC's Trade Facilitation Agenda. Vancouver: Asia Pacific Foundation of Canada. Available at: http://www.apec.org/Groups/Committee-on-Trade-and Investment/ /media/Files/Groups/MAG/01_cti_tradefacilitatn.ashx

Wilson, S. J., M. Catherine, Y. Woo Pau, A. Nizar, and C. Inbom (2009), 'Trade Facilitation: A Development Perspective in the Asia Pacific Region', Asia Pacific Economic Cooperation. Available at: http://siteresources.worldbank.org/INTRES/Resources/20929_APEC_TF_Re port_Final.pdf

\section{ENDNOTES}

1 "Economic theory generates a relatively simple chain of causality: human development is enhanced through income growth, income growth is greater with more cross-border trade, and trade is increased through trade facilitation efforts" Trade Facilitation: A Development Perspective in the Asia Pacific Region

${ }^{2}$ WB Viewpoint 
${ }^{3}$ The EAC Blueprint was signed in the ASEAN Summit in 2007, and the ASEAN community was to be established by 2015, as envisioned in the ASEAN Vision 2020 and the ASEAN Concord II

${ }^{4}$ Trade Logistics Reforms Viewpoint WB

5 http://www.miti.gov.my/cms/content.jsp?id=com.tms.cms.article.Article_b5e22087-c0a81573aba0aba0-ab12873b

${ }^{6}$ AEC Blueprint

${ }^{7}$ AEC Blueprint

${ }^{8}$ AEC Blueprint

${ }^{9}$ Brunei Darussalam, Indonesia, Malaysia, Philippines, Thailand and Singapore agreed their NSW would be fully functional by 2008

${ }^{10}$ Members included in the scale-down pilot were Brunei Darussalam, Indonesia, Malaysia, Philippines, Singapore, Thailand and Vietnam.

${ }^{11}$ Model of Ecommerce law UN

${ }^{12}$ The Andean Community of Nations is composed by Colombia, Bolivia, Peru and Ecuador. Venezuela withdrew its membership on 2006, but keeps partial agreements with the block as a whole to be able to continue steady trade.

13 OECD Gloria Cañas document

${ }^{14}$ Interview to Angela Ospina. June 20, 2013.

${ }^{15}$ PAA memebers: Singapore, Chinese Taipei, Hong Kong, Korea, China Japan, Malaysia, Macao, Thailand, Phillippines and Indonesia.

${ }^{16}$ Pagina de internet de PAA

${ }^{17} \mathrm{http} / / /$ www.asycuda.org/countrydb.asp?regfilter=2\&submit1=Filter

${ }^{18}$ USAID RADDEx

${ }^{19}$ USAID RADDEx 


\section{ERIA Discussion Paper Series}

\begin{tabular}{|c|c|c|c|}
\hline No. & Author(s) & Title & Year \\
\hline $2013-29$ & $\begin{array}{l}\text { Jonathan } \mathrm{KOH} \text { and } \\
\text { Andrea Feldman } \\
\text { MOWERMAN }\end{array}$ & $\begin{array}{l}\text { Towards a Truly Seamless Single Windows and } \\
\text { Trade Facilitation Regime in ASEAN Beyond } \\
2015\end{array}$ & $\begin{array}{l}\text { Nov } \\
2013\end{array}$ \\
\hline $2013-28$ & Rajah RASIAH & $\begin{array}{l}\text { Stimulating Innovation in ASEAN Institutional } \\
\text { Support, R\&D Activity and Intelletual Property } \\
\text { Rights }\end{array}$ & $\begin{array}{l}\text { Nov } \\
2013\end{array}$ \\
\hline $2013-27$ & $\begin{array}{l}\text { Maria Monica } \\
\text { WIHARDJA }\end{array}$ & $\begin{array}{l}\text { Financial Integration Challenges in ASEAN } \\
\text { beyond } 2015\end{array}$ & $\begin{array}{l}\text { Nov } \\
2013\end{array}$ \\
\hline $2013-26$ & $\begin{array}{l}\text { Tomohiro MACHIKITA } \\
\text { and Yasushi UEKI }\end{array}$ & $\begin{array}{l}\text { Who Disseminates Technology to Whom, How, } \\
\text { and Why: Evidence from Buyer-Seller Business } \\
\text { Networks }\end{array}$ & $\begin{array}{l}\text { Nov } \\
2013\end{array}$ \\
\hline $2013-25$ & Fukunari KIMURA & $\begin{array}{l}\text { Reconstructing the Concept of “Single Market a } \\
\text { Production Base” for ASEAN beyond } 2015\end{array}$ & $\begin{array}{l}\text { Oct } \\
2013\end{array}$ \\
\hline $2013-24$ & $\begin{array}{l}\text { Olivier CADOT } \\
\text { Ernawati MUNADI } \\
\text { Lili Yan ING }\end{array}$ & $\begin{array}{l}\text { Streamlining NTMs in ASEAN: } \\
\text { The Way Forward }\end{array}$ & $\begin{array}{l}\text { Oct } \\
2013\end{array}$ \\
\hline $2013-23$ & $\begin{array}{l}\text { Charles HARVIE, } \\
\text { Dionisius NARJOKO, } \\
\text { Sothea OUM }\end{array}$ & $\begin{array}{l}\text { Small and Medium Enterprises’ Access to } \\
\text { Finance: Evidence from Selected Asian } \\
\text { Economies }\end{array}$ & $\begin{array}{l}\text { Oct } \\
2013\end{array}$ \\
\hline $2013-22$ & Alan Khee-Jin TAN & $\begin{array}{l}\text { Toward a Single Aviation Market in ASEAN: } \\
\text { Regulatory Reform and Industry Challenges }\end{array}$ & $\begin{array}{l}\text { Oct } \\
2013\end{array}$ \\
\hline $2013-21$ & $\begin{array}{l}\text { Hisanobu SHISHIDO, } \\
\text { Shintaro SUGIYAMA, } \\
\text { Fauziah ZEN }\end{array}$ & $\begin{array}{l}\text { Moving MPAC Forward: Strengthening } \\
\text { Public-Private Partnership, Improving Project } \\
\text { Portfolio and in Search of Practical Financing } \\
\text { Schemes }\end{array}$ & $\begin{array}{l}\text { Oct } \\
2013\end{array}$ \\
\hline $2013-20$ & $\begin{array}{l}\text { Barry DESKER, Mely } \\
\text { CABALLERO-ANTH } \\
\text { ONY, Paul TENG }\end{array}$ & $\begin{array}{l}\text { Thought/Issues Paper on ASEAN Food Security: } \\
\text { Towards a more Comprehensive Framework }\end{array}$ & $\begin{array}{l}\text { Oct } \\
2013\end{array}$ \\
\hline 2013-19 & $\begin{array}{l}\text { Toshihiro KUDO, } \\
\text { Satoru KUMAGAI, So } \\
\text { UMEZAKI }\end{array}$ & $\begin{array}{l}\text { Making Myanmar the Star Growth Performer in } \\
\text { ASEAN in the Next Decade: A Proposal of Five } \\
\text { Growth Strategies }\end{array}$ & $\begin{array}{l}\text { Sep } \\
2013\end{array}$ \\
\hline
\end{tabular}




\begin{tabular}{|c|c|c|c|}
\hline No. & Author(s) & Title & Year \\
\hline 2013-18 & Ruperto MAJUCA & $\begin{array}{l}\text { Managing Economic Shocks and } \\
\text { Macroeconomic Coordination in an Integrated } \\
\text { Region: ASEAN Beyond } 2015\end{array}$ & $\begin{array}{l}\text { Sep } \\
2013\end{array}$ \\
\hline 2013-17 & $\begin{array}{l}\text { Cassy LEE and Yoshifumi } \\
\text { FUKUNAGA }\end{array}$ & $\begin{array}{l}\text { Competition Policy Challenges of Single Market } \\
\text { and Production Base }\end{array}$ & $\begin{array}{l}\text { Sep } \\
2013\end{array}$ \\
\hline 2013-16 & Simon TAY & $\begin{array}{l}\text { Growing an ASEAN Voice? : A Common } \\
\text { Platform in Global and Regional Governance }\end{array}$ & $\begin{array}{l}\text { Sep } \\
2013\end{array}$ \\
\hline $2013-15$ & $\begin{array}{l}\text { Danilo C. ISRAEL and } \\
\text { Roehlano M. BRIONES }\end{array}$ & $\begin{array}{l}\text { Impacts of Natural Disasters on Agriculture, Food } \\
\text { Security, and Natural Resources and Environment in } \\
\text { the Philippines }\end{array}$ & $\begin{array}{l}\text { Aug } \\
2013\end{array}$ \\
\hline $2013-14$ & $\begin{array}{l}\text { Allen Yu-Hung LAI and } \\
\text { Seck L. TAN }\end{array}$ & $\begin{array}{l}\text { Impact of Disasters and Disaster Risk Management in } \\
\text { Singapore: A Case Study of Singapore's Experience } \\
\text { in Fighting the SARS Epidemic }\end{array}$ & $\begin{array}{l}\text { Aug } \\
2013\end{array}$ \\
\hline $2013-13$ & Brent LAYTON & $\begin{array}{l}\text { Impact of Natural Disasters on Production Networks } \\
\text { and Urbanization in New Zealand }\end{array}$ & $\begin{array}{l}\text { Aug } \\
2013\end{array}$ \\
\hline $2013-12$ & Mitsuyo ANDO & $\begin{array}{l}\text { Impact of Recent Crises and Disasters on Regional } \\
\text { Production/Distribution Networks and Trade in Japan }\end{array}$ & $\begin{array}{l}\text { Aug } \\
2013\end{array}$ \\
\hline 2013-11 & Le Dang TRUNG & $\begin{array}{l}\text { Economic and Welfare Impacts of Disasters in East } \\
\text { Asia and Policy Responses: The Case of Vietnam }\end{array}$ & $\begin{array}{l}\text { Aug } \\
2013\end{array}$ \\
\hline $2013-10$ & $\begin{array}{l}\text { Sann VATHANA, Sothea } \\
\text { OUM, Ponhrith KAN, } \\
\text { Colas CHERVIER }\end{array}$ & $\begin{array}{l}\text { Impact of Disasters and Role of Social Protection in } \\
\text { Natural Disaster Risk Management in Cambodia }\end{array}$ & $\begin{array}{l}\text { Aug } \\
2013\end{array}$ \\
\hline 2013-09 & $\begin{array}{l}\text { Sommarat CHANTARAT, } \\
\text { Krirk PANNANGPETCH, } \\
\text { Nattapong } \\
\text { PUTTANAPONG, Preesan } \\
\text { RAKWATIN, and Thanasin } \\
\text { TANOMPONGPHANDH }\end{array}$ & $\begin{array}{l}\text { Index-Based Risk Financing and Development of } \\
\text { Natural Disaster Insurance Programs in Developing } \\
\text { Asian Countries }\end{array}$ & $\begin{array}{l}\text { Aug } \\
2013\end{array}$ \\
\hline 2013-08 & $\begin{array}{l}\text { Ikumo ISONO and Satoru } \\
\text { KUMAGAI }\end{array}$ & $\begin{array}{l}\text { Long-run Economic Impacts of Thai Flooding: } \\
\text { Geographical Simulation Analysis }\end{array}$ & $\begin{array}{l}\text { July } \\
2013\end{array}$ \\
\hline 2013-07 & $\begin{array}{l}\text { Yoshifumi FUKUNAGA } \\
\text { and Hikaru ISHIDO }\end{array}$ & $\begin{array}{l}\text { Assessing the Progress of Services Liberalization in } \\
\text { the ASEAN-China Free Trade Area (ACFTA) }\end{array}$ & $\begin{array}{l}\text { May } \\
2013\end{array}$ \\
\hline 2013-06 & Ken ITAKURA, Yoshifumi & A CGE Study of Economic Impact of Accession of & May \\
\hline
\end{tabular}




\begin{tabular}{|c|c|c|c|}
\hline No. & Author(s) & Title & Year \\
\hline & FUKUNAGA, and Ikumo & Hong Kong to ASEAN-China Free Trade Agreement & 2013 \\
\hline & ISONO & & \\
\hline \multirow{2}{*}{ 2013-05 } & Misa OKABE and Shujiro & \multirow{2}{*}{ The Impact of AFTA on Intra-AFTA Trade } & May \\
\hline & URATA & & 2013 \\
\hline \multirow{2}{*}{ 2013-04 } & \multirow{2}{*}{ Kohei SHIINO } & How Far Will Hong Kong’s Accession to ACFTA will & May \\
\hline & & Impact on Trade in Goods? & 2013 \\
\hline \multirow{2}{*}{ 2013-03 } & Cassey LEE and Yoshifumi & ASEAN Regional Cooperation on Competition & Apr \\
\hline & FUKUNAGA & Policy & 2013 \\
\hline \multirow[b]{2}{*}{ 2013-02 } & \multirow{2}{*}{$\begin{array}{l}\text { Yoshifumi FUKUNAGA } \\
\text { and Ikumo ISONO }\end{array}$} & \multirow{2}{*}{$\begin{array}{l}\text { Taking ASEAN+1 FTAs towards the RCEP: } \\
\text { A Mapping Study }\end{array}$} & Jan \\
\hline & & & 2013 \\
\hline \multirow{3}{*}{ 2013-01 } & \multirow{3}{*}{ Ken ITAKURA } & \multirow{3}{*}{$\begin{array}{l}\text { Impact of Liberalization and Improved Connectivity } \\
\text { and Facilitation in ASEAN for the ASEAN Economic } \\
\text { Community }\end{array}$} & \\
\hline & & & \\
\hline & & & 2013 \\
\hline \multirow{2}{*}{ 2012-17 } & Sun XUEGONG, Guo & Market Entry Barriers for FDI and Private Investors: & Aug \\
\hline & LIYAN, Zeng ZHENG & Lessons from China's Electricity Market & 2012 \\
\hline \multirow{2}{*}{ 2012-16 } & \multirow{2}{*}{ Yanrui WU } & Electricity Market Integration: Global Trends and & Aug \\
\hline & & Implications for the EAS Region & 2012 \\
\hline \multirow{2}{*}{$2012-15$} & \multirow{2}{*}{$\begin{array}{l}\text { Youngho CHANG, Yanfei } \\
\text { LI }\end{array}$} & \multirow{2}{*}{$\begin{array}{l}\text { Power Generation and Cross-border Grid Planning for } \\
\text { the Integrated ASEAN Electricity Market: A Dynamic } \\
\text { Linear Programming Model }\end{array}$} & Aug \\
\hline & & & 2012 \\
\hline \multirow{2}{*}{ 2012-14 } & \multirow{2}{*}{ Yanrui WU, Xunpeng SHI } & Economic Development, Energy Market Integration and & Aug \\
\hline & & Energy Demand: Implications for East Asia & 2012 \\
\hline \multirow{3}{*}{ 2012-13 } & Joshua AIZENMAN, & The Relationship between Structural Change and & \multirow{3}{*}{$\begin{array}{l}\text { July } \\
2012\end{array}$} \\
\hline & Minsoo LEE, and & Inequality: A Conceptual Overview with Special & \\
\hline & Donghyun PARK & Reference to Developing Asia & \\
\hline \multirow{2}{*}{ 2012-12 } & Hyun-Hoon LEE, Minsoo & Growth Policy and Inequality in Developing Asia: & July \\
\hline & LEE, and Donghyun PARK & Lessons from Korea & 2012 \\
\hline \multirow{2}{*}{ 2012-11 } & \multirow{2}{*}{ Cassey LEE } & Knowledge Flows, Organization and Innovation: & June \\
\hline & & Firm-Level Evidence from Malaysia & 2012 \\
\hline \multirow{2}{*}{ 2012-10 } & \multirow{2}{*}{$\begin{array}{l}\text { Jacques MAIRESSE, Pierre } \\
\text { MOHNEN, Yayun ZHAO, } \\
\text { and Feng ZHEN }\end{array}$} & \multirow{2}{*}{$\begin{array}{l}\text { Globalization, Innovation and Productivity in } \\
\text { Manufacturing Firms: A Study of Four Sectors of China }\end{array}$} & \multirow{2}{*}{$\begin{array}{l}\text { June } \\
2012\end{array}$} \\
\hline & & & \\
\hline 2012-09 & Ari KUNCORO & Globalization and Innovation in Indonesia: Evidence & June \\
\hline
\end{tabular}




\begin{tabular}{|c|c|c|c|}
\hline No. & Author(s) & Title & Year \\
\hline & & $\begin{array}{l}\text { from Micro-Data on Medium and Large Manufacturing } \\
\text { Establishments }\end{array}$ & 2012 \\
\hline 2012-08 & Alfons PALANGKARAYA & $\begin{array}{l}\text { The Link between Innovation and Export: Evidence } \\
\text { from Australia's Small and Medium Enterprises }\end{array}$ & $\begin{array}{l}\text { June } \\
2012\end{array}$ \\
\hline 2012-07 & $\begin{array}{l}\text { Chin Hee HAHN and } \\
\text { Chang-Gyun PARK }\end{array}$ & $\begin{array}{l}\text { Direction of Causality in Innovation-Exporting Linkage: } \\
\text { Evidence on Korean Manufacturing }\end{array}$ & $\begin{array}{l}\text { June } \\
2012\end{array}$ \\
\hline 2012-06 & Keiko ITO & $\begin{array}{l}\text { Source of Learning-by-Exporting Effects: Does } \\
\text { Exporting Promote Innovation? }\end{array}$ & $\begin{array}{l}\text { June } \\
2012\end{array}$ \\
\hline 2012-05 & Rafaelita M. ALDABA & $\begin{array}{l}\text { Trade Reforms, Competition, and Innovation in the } \\
\text { Philippines }\end{array}$ & $\begin{array}{l}\text { June } \\
2012\end{array}$ \\
\hline 2012-04 & $\begin{array}{l}\text { Toshiyuki MATSUURA } \\
\text { and Kazunobu } \\
\text { HAYAKAWA }\end{array}$ & $\begin{array}{l}\text { The Role of Trade Costs in FDI Strategy of } \\
\text { Heterogeneous Firms: Evidence from Japanese } \\
\text { Firm-level Data }\end{array}$ & $\begin{array}{l}\text { June } \\
2012\end{array}$ \\
\hline 2012-03 & $\begin{array}{l}\text { Kazunobu HAYAKAWA, } \\
\text { Fukunari KIMURA, and } \\
\text { Hyun-Hoon LEE }\end{array}$ & $\begin{array}{l}\text { How Does Country Risk Matter for Foreign Direct } \\
\text { Investment? }\end{array}$ & $\begin{array}{l}\text { Feb } \\
2012\end{array}$ \\
\hline 2012-02 & $\begin{array}{l}\text { Ikumo ISONO, Satoru } \\
\text { KUMAGAI, Fukunari } \\
\text { KIMURA }\end{array}$ & $\begin{array}{l}\text { Agglomeration and Dispersion in China and ASEAN: } \\
\text { A Geographical Simulation Analysis }\end{array}$ & $\begin{array}{l}\text { Jan } \\
2012\end{array}$ \\
\hline 2012-01 & $\begin{array}{l}\text { Mitsuyo ANDO and } \\
\text { Fukunari KIMURA }\end{array}$ & $\begin{array}{l}\text { How Did the Japanese Exports Respond to Two Crises } \\
\text { in the International Production Network?: The Global } \\
\text { Financial Crisis and the East Japan Earthquake }\end{array}$ & $\begin{array}{l}\text { Jan } \\
2012\end{array}$ \\
\hline 2011-10 & $\begin{array}{l}\text { Tomohiro MACHIKITA } \\
\text { and Yasushi UEKI }\end{array}$ & $\begin{array}{l}\text { Interactive Learning-driven Innovation in } \\
\text { Upstream-Downstream Relations: Evidence from } \\
\text { Mutual Exchanges of Engineers in Developing } \\
\text { Economies }\end{array}$ & $\begin{array}{l}\text { Dec } \\
2011\end{array}$ \\
\hline 2011-09 & $\begin{array}{l}\text { Joseph D. ALBA, Wai-Mun } \\
\text { CHIA, and Donghyun } \\
\text { PARK }\end{array}$ & $\begin{array}{l}\text { Foreign Output Shocks and Monetary Policy Regimes } \\
\text { in Small Open Economies: A DSGE Evaluation of East } \\
\text { Asia }\end{array}$ & $\begin{array}{l}\text { Dec } \\
2011\end{array}$ \\
\hline 2011-08 & $\begin{array}{l}\text { Tomohiro MACHIKITA } \\
\text { and Yasushi UEKI }\end{array}$ & $\begin{array}{l}\text { Impacts of Incoming Knowledge on Product Innovation: } \\
\text { Econometric Case Studies of Technology Transfer of } \\
\text { Auto-related Industries in Developing Economies }\end{array}$ & $\begin{array}{l}\text { Nov } \\
2011\end{array}$ \\
\hline 2011-07 & Yanrui WU & $\begin{array}{l}\text { Gas Market Integration: Global Trends and Implications } \\
\text { for the EAS Region }\end{array}$ & $\begin{array}{l}\text { Nov } \\
2011\end{array}$ \\
\hline
\end{tabular}




\begin{tabular}{|c|c|c|c|}
\hline No. & Author(s) & Title & Year \\
\hline \multirow{2}{*}{ 2011-06 } & \multirow{2}{*}{ Philip Andrews-SPEED } & Energy Market Integration in East Asia: A Regional & Nov \\
\hline & & Public Goods Approach & 2011 \\
\hline \multirow{2}{*}{ 2011-05 } & Yu SHENG, & Energy Market Integration and Economic & Oct \\
\hline & Xunpeng SHI & Convergence: Implications for East Asia & 2011 \\
\hline \multirow{3}{*}{ 2011-04 } & Sang-Hyop LEE, Andrew & Why Does Population Aging Matter So Much for & \multirow{3}{*}{$\begin{array}{l}\text { Aug } \\
2011\end{array}$} \\
\hline & MASON, and Donghyun & Asia? Population Aging, Economic Security and & \\
\hline & PARK & Economic Growth in Asia & \\
\hline \multirow{2}{*}{ 2011-03 } & Xunpeng SHI, & Harmonizing Biodiesel Fuel Standards in East Asia: & May \\
\hline & Shinichi GOTO & Current Status, Challenges and the Way Forward & 2011 \\
\hline \multirow{2}{*}{ 2011-02 } & \multirow{2}{*}{ Hikari ISHIDO } & Liberalization of Trade in Services under ASEAN+n : & May \\
\hline & & A Mapping Exercise & 2011 \\
\hline \multirow{3}{*}{ 2011-01 } & Kuo-I CHANG, Kazunobu & \multirow{3}{*}{$\begin{array}{l}\text { Location Choice of Multinational Enterprises in } \\
\text { China: Comparison between Japan and Taiwan }\end{array}$} & \multirow{3}{*}{$\begin{array}{l}\text { Mar } \\
2011\end{array}$} \\
\hline & HAYAKAWA & & \\
\hline & Toshiyuki MATSUURA & & \\
\hline \multirow{2}{*}{ 2010-11 } & \multirow{2}{*}{$\begin{array}{l}\text { Charles HARVIE, } \\
\text { Dionisius NARJOKO, } \\
\text { Sothea OUM }\end{array}$} & \multirow{2}{*}{$\begin{array}{l}\text { Firm Characteristic Determinants of SME } \\
\text { Participation in Production Networks }\end{array}$} & \multirow{2}{*}{$\begin{array}{l}\text { Oct } \\
2010\end{array}$} \\
\hline & & & \\
\hline \multirow{2}{*}{ 2010-10 } & \multirow{2}{*}{ Mitsuyo ANDO } & Machinery Trade in East Asia, and the Global & Oct \\
\hline & & Financial Crisis & 2010 \\
\hline \multirow{2}{*}{ 2010-09 } & Fukunari KIMURA & International Production Networks in Machinery & Sep \\
\hline & Ayako OBASHI & Industries: Structure and Its Evolution & 2010 \\
\hline 2010-08 & $\begin{array}{l}\text { Tomohiro MACHIKITA, } \\
\text { Shoichi MIYAHARA, } \\
\text { Masatsugu TSUJI, and } \\
\text { Yasushi UEKI }\end{array}$ & $\begin{array}{l}\text { Detecting Effective Knowledge Sources in Product } \\
\text { Innovation: Evidence from Local Firms and } \\
\text { MNCs/JVs in Southeast Asia }\end{array}$ & $\begin{array}{l}\text { Aug } \\
2010\end{array}$ \\
\hline 2010-07 & $\begin{array}{l}\text { Tomohiro MACHIKITA, } \\
\text { Masatsugu TSUJI, and } \\
\text { Yasushi UEKI }\end{array}$ & $\begin{array}{l}\text { How ICTs Raise Manufacturing Performance: } \\
\text { Firm-level Evidence in Southeast Asia }\end{array}$ & $\begin{array}{l}\text { Aug } \\
2010\end{array}$ \\
\hline \multirow{3}{*}{ 2010-06 } & \multirow{3}{*}{ Xunpeng SHI } & Carbon Footprint Labeling Activities in the East Asia & \multirow{3}{*}{$\begin{array}{l}\text { July } \\
2010\end{array}$} \\
\hline & & Summit Region: Spillover Effects to Less Developed & \\
\hline & & Countries & \\
\hline \multirow{2}{*}{ 2010-05 } & Kazunobu HAYAKAWA, & Firm-level Analysis of Globalization: A Survey of the & Mar \\
\hline & Fukunari KIMURA, and & Eight Literatures & 2010 \\
\hline
\end{tabular}




\begin{tabular}{|c|c|c|c|}
\hline No. & Author(s) & Title & Year \\
\hline & Tomohiro MACHIKITA & & \\
\hline 2010-04 & $\begin{array}{l}\text { Tomohiro MACHIKITA } \\
\text { and Yasushi UEKI }\end{array}$ & $\begin{array}{l}\text { The Impacts of Face-to-face and Frequent } \\
\text { Interactions on Innovation: } \\
\text { Upstream-Downstream Relations }\end{array}$ & $\begin{array}{l}\text { Feb } \\
2010\end{array}$ \\
\hline 2010-03 & $\begin{array}{l}\text { Tomohiro MACHIKITA } \\
\text { and Yasushi UEKI }\end{array}$ & $\begin{array}{l}\text { Innovation in Linked and Non-linked Firms: } \\
\text { Effects of Variety of Linkages in East Asia }\end{array}$ & $\begin{array}{l}\text { Feb } \\
2010\end{array}$ \\
\hline 2010-02 & $\begin{array}{l}\text { Tomohiro MACHIKITA } \\
\text { and Yasushi UEKI }\end{array}$ & $\begin{array}{l}\text { Search-theoretic Approach to Securing New } \\
\text { Suppliers: Impacts of Geographic Proximity for } \\
\text { Importer and Non-importer }\end{array}$ & $\begin{array}{l}\text { Feb } \\
2010\end{array}$ \\
\hline 2010-01 & $\begin{array}{l}\text { Tomohiro MACHIKITA } \\
\text { and Yasushi UEKI }\end{array}$ & $\begin{array}{l}\text { Spatial Architecture of the Production Networks in } \\
\text { Southeast Asia: } \\
\text { Empirical Evidence from Firm-level Data }\end{array}$ & $\begin{array}{l}\text { Feb } \\
2010\end{array}$ \\
\hline $2009-23$ & Dionisius NARJOKO & $\begin{array}{l}\text { Foreign Presence Spillovers and Firms’ Export } \\
\text { Response: } \\
\text { Evidence from the Indonesian Manufacturing }\end{array}$ & $\begin{array}{l}\text { Nov } \\
2009\end{array}$ \\
\hline $2009-22$ & $\begin{array}{l}\text { Kazunobu HAYAKAWA, } \\
\text { Daisuke HIRATSUKA, } \\
\text { Kohei SHIINO, and Seiya } \\
\text { SUKEGAWA }\end{array}$ & Who Uses Free Trade Agreements? & $\begin{array}{l}\text { Nov } \\
2009\end{array}$ \\
\hline $2009-21$ & Ayako OBASHI & $\begin{array}{l}\text { Resiliency of Production Networks in Asia: } \\
\text { Evidence from the Asian Crisis }\end{array}$ & $\begin{array}{l}\text { Oct } \\
2009\end{array}$ \\
\hline $2009-20$ & $\begin{array}{l}\text { Mitsuyo ANDO and } \\
\text { Fukunari KIMURA }\end{array}$ & Fragmentation in East Asia: Further Evidence & $\begin{array}{l}\text { Oct } \\
2009\end{array}$ \\
\hline 2009-19 & Xunpeng SHI & $\begin{array}{l}\text { The Prospects for Coal: Global Experience and } \\
\text { Implications for Energy Policy }\end{array}$ & $\begin{array}{l}\text { Sept } \\
2009\end{array}$ \\
\hline $2009-18$ & Sothea OUM & $\begin{array}{l}\text { Income Distribution and Poverty in a CGE } \\
\text { Framework: A Proposed Methodology }\end{array}$ & $\begin{array}{l}\text { Jun } \\
2009\end{array}$ \\
\hline $2009-17$ & $\begin{array}{l}\text { Erlinda M. MEDALLA } \\
\text { and Jenny BALBOA }\end{array}$ & $\begin{array}{l}\text { ASEAN Rules of Origin: Lessons and } \\
\text { Recommendations for the Best Practice }\end{array}$ & $\begin{array}{l}\text { Jun } \\
2009\end{array}$ \\
\hline $2009-16$ & Masami ISHIDA & Special Economic Zones and Economic Corridors & $\begin{array}{l}\text { Jun } \\
2009\end{array}$ \\
\hline $2009-15$ & Toshihiro KUDO & $\begin{array}{l}\text { Border Area Development in the GMS: Turning the } \\
\text { Periphery into the Center of Growth }\end{array}$ & $\begin{array}{l}\text { May } \\
2009\end{array}$ \\
\hline 2009-14 & Claire HOLLWEG and & Measuring Regulatory Restrictions in Logistics & Apr \\
\hline
\end{tabular}




\begin{tabular}{|c|c|c|c|}
\hline No. & Author(s) & Title & Year \\
\hline & Marn-Heong WONG & Services & 2009 \\
\hline $2009-13$ & Loreli C. De DIOS & Business View on Trade Facilitation & $\begin{array}{l}\text { Apr } \\
2009\end{array}$ \\
\hline $2009-12$ & $\begin{array}{l}\text { Patricia SOURDIN and } \\
\text { Richard POMFRET }\end{array}$ & Monitoring Trade Costs in Southeast Asia & $\begin{array}{l}\text { Apr } \\
2009\end{array}$ \\
\hline 2009-11 & $\begin{array}{l}\text { Philippa DEE and } \\
\text { Huong DINH }\end{array}$ & $\begin{array}{l}\text { Barriers to Trade in Health and Financial Services in } \\
\text { ASEAN }\end{array}$ & $\begin{array}{l}\text { Apr } \\
2009\end{array}$ \\
\hline $2009-10$ & Sayuri SHIRAI & $\begin{array}{l}\text { The Impact of the US Subprime Mortgage Crisis on } \\
\text { the World and East Asia: Through Analyses of } \\
\text { Cross-border Capital Movements }\end{array}$ & $\begin{array}{l}\text { Apr } \\
2009\end{array}$ \\
\hline 2009-09 & $\begin{array}{l}\text { Mitsuyo ANDO and } \\
\text { Akie IRIYAMA }\end{array}$ & $\begin{array}{l}\text { International Production Networks and Export/Import } \\
\text { Responsiveness to Exchange Rates: The Case of } \\
\text { Japanese Manufacturing Firms }\end{array}$ & $\begin{array}{l}\text { Mar } \\
2009\end{array}$ \\
\hline 2009-08 & Archanun & Vertical and Horizontal FDI Technology & Mar \\
\hline & KOHPAIBOON & Spillovers:Evidence from Thai Manufacturing & 2009 \\
\hline 2009-07 & $\begin{array}{l}\text { Kazunobu HAYAKAWA, } \\
\text { Fukunari KIMURA, and } \\
\text { Toshiyuki MATSUURA }\end{array}$ & $\begin{array}{l}\text { Gains from Fragmentation at the Firm Level: } \\
\text { Evidence from Japanese Multinationals in East Asia }\end{array}$ & $\begin{array}{l}\text { Mar } \\
2009\end{array}$ \\
\hline 2009-06 & Dionisius A. NARJOKO & $\begin{array}{l}\text { Plant Entry in a More } \\
\text { LiberalisedIndustrialisationProcess: An Experience } \\
\text { of Indonesian Manufacturing during the 1990s }\end{array}$ & $\begin{array}{l}\text { Mar } \\
2009\end{array}$ \\
\hline 2009-05 & $\begin{array}{l}\text { Kazunobu HAYAKAWA, } \\
\text { Fukunari KIMURA, and } \\
\text { Tomohiro MACHIKITA }\end{array}$ & Firm-level Analysis of Globalization: A Survey & $\begin{array}{l}\text { Mar } \\
2009\end{array}$ \\
\hline 2009-04 & $\begin{array}{l}\text { Chin Hee HAHN and } \\
\text { Chang-Gyun PARK }\end{array}$ & $\begin{array}{l}\text { Learning-by-exporting in Korean Manufacturing: } \\
\text { A Plant-level Analysis }\end{array}$ & $\begin{array}{l}\text { Mar } \\
2009\end{array}$ \\
\hline 2009-03 & Ayako OBASHI & $\begin{array}{l}\text { Stability of Production Networks in East Asia: } \\
\text { Duration and Survival of Trade }\end{array}$ & $\begin{array}{l}\text { Mar } \\
2009\end{array}$ \\
\hline 2009-02 & Fukunari KIMURA & $\begin{array}{l}\text { The Spatial Structure of Production/Distribution } \\
\text { Networks and Its Implication for Technology } \\
\text { Transfers and Spillovers }\end{array}$ & $\begin{array}{l}\text { Mar } \\
2009\end{array}$ \\
\hline 2009-01 & $\begin{array}{l}\text { Fukunari KIMURA and } \\
\text { Ayako OBASHI }\end{array}$ & $\begin{array}{l}\text { International Production Networks: Comparison } \\
\text { between China and ASEAN }\end{array}$ & $\begin{array}{l}\text { Jan } \\
2009\end{array}$ \\
\hline
\end{tabular}




\begin{tabular}{|c|c|c|c|}
\hline No. & Author(s) & Title & Year \\
\hline 2008-03 & $\begin{array}{l}\text { Kazunobu HAYAKAWA } \\
\text { and Fukunari KIMURA }\end{array}$ & $\begin{array}{l}\text { The Effect of Exchange Rate Volatility on } \\
\text { International Trade in East Asia }\end{array}$ & $\begin{array}{l}\text { Dec } \\
2008\end{array}$ \\
\hline 2008-02 & $\begin{array}{l}\text { Satoru KUMAGAI, } \\
\text { Toshitaka GOKAN, } \\
\text { Ikumo ISONO, and } \\
\text { Souknilanh KEOLA }\end{array}$ & $\begin{array}{l}\text { Predicting Long-Term Effects of Infrastructure } \\
\text { Development Projects in Continental South East } \\
\text { Asia: IDE Geographical Simulation Model }\end{array}$ & $\begin{array}{l}\text { Dec } \\
2008\end{array}$ \\
\hline 2008-01 & $\begin{array}{l}\text { Kazunobu HAYAKAWA, } \\
\text { Fukunari KIMURA, and } \\
\text { Tomohiro MACHIKITA }\end{array}$ & Firm-level Analysis of Globalization: A Survey & $\begin{array}{l}\text { Dec } \\
2008\end{array}$ \\
\hline
\end{tabular}

